Herausgegeben vom Zentralen Geologischen Institut Berlin im Auftrag des Ministeriums für Geologie der Deutschen Demokratischen Republik

Verlag: Akademie-Verlag, 108 Berlin, Leipziger Straße 3-4

Schmidt, K.; Katzung, G.; Franke, D.

Yur Entwicklung des präpermischen Untergrunds und des Magmatismus im südwestlichen Vorfeld der 0steuropäischen Tafel

7. angew. Geol., Berlin, 23 (1977) 9, S. 426-436, 2 Abb., 95 Lit.

Ausgehend von den bisherigen Anschauungen über den Bau des Untergrunds im nördlichen Mitteleuropa werden Vorstellungen über die Entwicklung des Präperms und die Bedeutung des Magmatismus für die großräumige tektonisch Rayonierung dargelegt. Neben den bekannten Baueinheiten unterschiedlichen Konsolidations- bzw. Faltungsalters treten ein, ,herzynisch “ und ein ,rheinisch " orientiertes Bruchsystem hervor. Der den Zeitraum vom jüngsten Präkambrium bis zum Quartär umfassende Deckgebirgsmagmatismus weist entsprechend dem jeweiligen Krustenzustand alkalischen oder kalkalkalischen Chemismus auf und bildet die Kratonisierung in Zeit und Raum ab. Die bedeutendste Eruptivperiode war an die ausklingenden tektonischen Prozesse des variszi-
gchen Zyklus gebunden. Das meridionale und das dem Südwestrand der Ost-
europäischen Tafel parallele Bruchsystem haben diesen spätvariszischen Vulka. europäischen Tafel parallele Bruchsystem haben diesen spătvariszischen Vulkanismus gesteuert bzw. nachhaltig beeinflußt. Im Kreuzungsbereich beider des Deckgebirgsmagmatismus im nördlichen Mitteleuropa überhaupt.

Garezki, R. G.; AISBerg, R. E.; SuveJsDis, P. I. u. a.

Die Deckgebirgsstrukturen in der Bjelorussisehen SSR und in den baltischen Sowjetrepubliken

Z. angew. Geol., Berlin, 23 (1977) 9, S. 436-439, 1 Abb., 2 Lit.

Das Tafeldeckgebirge Bjelorußlands und des Baltikums gliedert sich in Strukturkomplexe, die Ausdruck der tektonischen Entwicklungsetappen der westlichen Russischen Platte der Osteuropasischen Tafel sind. Die großen Deckge birgsstrukturen lassen sich in ihrer zeitlich-räumlichen Entwicklung anhand von Strukturkarten beschreiben. Die Strukturpläne des unterriphäischen (?) früh- und spätbaikalischen und des kaledonischen Strukturkomplexes folgen etwa dem der Fundamentoberflăche. Zwar trifft das auch auf den variszischen Komplex $\mathrm{zu}$, jedoch sind für die variszischen Strukturen unterschiedliche De formationsgrade und -typen, Bruchtektonik sowie z. T. Salztektonik (Pripjatsenke) typisch. Der Strukturplan des kimmeris
gegenüber den liegenden Komplexen stark ab.

Znosko, J.

Über den geologischen Bau in der Zone der Tornquist-Teisseyre-Linie zwischen Ostsee und Swietokrzyskie Gory

Z. angew. Geol., Berlin 23 (1977) 9, S. 439-444, 56 Lit.

Das Gebiet im Bereich der Tornquist-Teisseyre-Linie, die südwestliche Randzone der präbaikalischen Osteuropäischen Tafel, zwischen Ostsee und Swietokrzyskie Gory, unterliegt einer Betrachtung. Es wird im weiteren auf den Mittclpolnischen Wall bzw. die Dänisch-Polnische Furche eingegangen, deren tekto-
nische und petrographische Entwicklung beschrieben werden. Die Dänischnische und petrographische Entwicklung beschrieben werden. Die Dänischdas Gebiet der VR Polen in zwei Teile: in einen nordöstlichen präbaikalisch konsolidierten und in einen südwestlichen, der zur paläozoischen Tektonik gehört. In diesem Zusammenhang wird das Problem Verbreitungsgrenze der Varisziden und der Beginn der sudetischen Vortiefe noch einmal aufgegriffen Bereits bestehende Ansichten (STLLE) iber die Genese des behandelten Raums Bereits bestehende Ansichten (STILL) über die Genese des behandelten Raum
kounten durch neuere Forschungen des Autors bestätigt und erweitert werden.

\section{Moduí́ski, Z.}

Beitrag über die Ausbildung des Ordoviziums am Südwestrand der 0steuropäischen Tafel in der VR Polen

Z. angew. Geol, Berlin, 23 (1977) 9, S. 445-449, 3 Abb., 11 Lit.

Anhand einer Mächtigkeits- und Lithofaziesanalyse ordovizischer Ablagerungen wird ein Uberblick über die palïostrukturelle Entwicktung südwestlicher Rand bereiche der Osteuropäischen Tafel auf dem Territorium der VR Polen und angrenzender Gebiete für die Zeit des Ordoviziums gegeben. Ausgehend vom Bjelorussischen Massiv im E kann bis zum Tafelrand in W eine Reihe von Depressions- und Hebungszonen unterschieden werden, die sich im Ordoviziun entwickelten und sich wahrend des Caradoc und des Ashgill besonders deutlich hervorheben. Der unmittelbare Tafelrand wird als ein Bereich gedeutet, in dem die Sedimentationsraten hinter der Absenkungsgeschwindigkeit zurückblieben bzw. als ein Gebiet, dessen Sedimente durch submarine Erosion in die vorgelagerte Geosynklinale verlagert wurden. Die Kenntnis uber die Geosynklinalstrukturelle Untergliederung noch eine lithofazielle Analyse vorgenommen strukturelle Untergliederung noch eine lithofazielle Analyse vorgenommen der mittel- und oberkambrischen Entwicklung einerseits und der des Ordoviziun's zu erkennen.
Norling, E.; Skoglund, R.

Der Südwestrand der 0steuropäischen Tafel im Bereich Sehwedens Z. angew. Geol., Berlin, 23 (1977) 9, S. 449-458, 2 Abb., 4 Tab., 66 Lit. Verf. gibt einen Uberblick über neue Forschungsergebnisse am Südwestrand der Osteuropäischen Tafel im Bereich Schwedens. Er geht von den strukturgeologischen Verhältnissen aus, unterbaut sie mit den Ergebnissen der paläomagnetischen Forschung und den Kenntnissen über magmatische Erscheinungen und berichtet dann eingehend über die Stratigraphie, Lithologie und
Paläogeographie dieses Gebiets. Ein ausführliches Literaturverzeichnis beschließt and vervollständigt die Arbeit.

WALLISER, O. H.

Probleme der geotektonischen Einordnung der Varisziden

Z. angew. Geol., Berlin, 23 (1977) 9, S. 459-463, 30 Lit.

Die Varisziden Europas stellen ein proterozoisch-paläozoisch entwickeltes Tektogen dar. Der Aufbau seiner Kruste sowie die variszische Sedimentation und der Vplkanismus in diesem Zeitraum sprechen weder für die Entstehung nach dem typischen plattentektonischen Modell noch nach dem des fixistischen nach dem typischen plattentektonischen Modell noch nach dem des fixistischen Minheziehung differenzierter Konvektions-Mechanismen durch die zunehmende Einengung eines evtl. noch teilweise primär relativ mobilen, sialischen Krustenfelds zwischen den sich nähernden Kontinenten Laurentia, Fennosarmatia und Gondwana erklären. Die Varisziden Europas bieten damit einen Anhaltspunkt für eine im weiten Sinne gerichtete Evolution sowohl der Ursachen, als auch der Auswirkungen tektogener Vorgänge.

\section{PAPROTH, E.}

\section{Zur Problematik des IGCP-Projekts 86}

Z. angew. Geol., Berlin 23 (1977) 0, S. 463-465, 2 Abb., 12 Lit.

DUnNing, F. W.; Watson, J.

Ctber die mögliche Erstreekung der 0steuropäischen Tafel bis England und Wales

Z. angew. Geol., Berlin 23 (1977) 9, S. 465-470, 2 Abb., 14 Lit.

In Zentralengland ist verschiedentlich das präkambrische Fundament des Midlandkratons aufgeschlossen. Fs sind metamorphe Gesteine, die von einer sehr wahrscheinlich jüngstpräkambrıschen vulkanisch-sedimentären Serie úberlagert werden. Das Altpaläozoikum ist in den westlich angrenzenden Kaledoniden in mächtiger Geosynklinalfazies entwickelt, über dem Midlandkraton liegt es in geringmächtiger, lückenhaiter Tafelfazies vor bzw. fehlt auf großen Flächen vőllig; auch in Südostengland wurde gefaltetes geosynklinales Altpaliozoikum erbohrt. Devon in Old-Red-Fazies ist vor allen in Südostwales und in der Umgebung von London verbreitet; große Teile des Midlandkratons werden direkt vom karbonischen (und jüngeren) Deckgebirge überlagert. Die Süd- und die Nordwestbegrenzung des Midlandkratons sind hinreichend sicher fixiert.

Garezkr, R. G.; Aisberg, R. E.

Bau und Entwicklungsetappen der westlichen Osteuropäischen Tafel innerhalb der Bjelorussischen SSR und benachbarter Gebiete

Z. angew. Geol., Berlin 23 (1977) 9, S. 470-478, 6 Abb., 1 Tab.

Das Territorium der Bjelorussischen SSR wird weitgehend von der Russischen Platte, untergeordnet vom Ukrainischen Schild und der Wolhynisch-Asowschen Platte, die Bestandteile der Osteuropäischen Tafel sind, eingenommen. Anschließend an eine Beschreibung der einzelnen Großstrukturen wird die tektonische Entwicklung, die sich in den Tafeldeckgebirgsstrukturen widerspiegelt, in Etappen dargestellt. Hauptetappen der Tafelentwicklung sind die unterriphăische Quasitafeletappe, die mittelriphăisch-unterwendische Katatafeletappe sowie die oberwendisch-phanerozoische Orthotafeletappe.

Koltschanow, W. P.

Uber die Darstellung von Tafelgebieten uuf der Tektonischen Karte des Südwestrands der Osteuropäischen Tafel (IGCP-Projekt 86)

Z. angew. Geol., Berlin, 23 (1977) 9, S. 479-481

Dargestellt werden Grundsätze und Methoden für die Bearbeitung einer tektonischen Karte im Rahmen des IGCP-Projekts 86 (Südwestrandzone der Osteuropãischen Tafel). Hauptcharakteristika der Tafelgebiete - Konsolidations Isolinien wernachenlage des Fundaments - werden durch Farben bzw. linien einer Reihe die Darstellung von Falten- und Bruchstrukturen versehiedener (ienese und GröBenordnung. 
Herausgegeben vom Zentralen Geologischen Institut Berlin im Auftrag des Ministeriums für Geologie der Deutschen Demokratischen Republik

Verlag: Akademie-Verlag, 108 Berlin, Leipziger Straße 3-4

Schmidt, K.; Katzung, G.; Franke, D.

The Development of the Prepermian Basement and of the Magmatism in the Southwestern Margin of the Eastern European Platform

Z. angew. Geol., Berlin, 23 (1977) 9, pp. 426-436, 2 Figs., 95 Refs. On the basis of views so far held on the basement structure in northern Central Europe ideas are presented on the Prepermian development and importance of magmatism to the large-area tectonic regional division, giving prominence to a "Hercynian " and "Rhenish" or ientated system of faults in addition to already known tectonic units of different age of consolidation or folding. In accordance with the crustal state the cover magmatism including the period alk the Latest Precambrian to the Qualernary shows an alkaline, or calcalkaline, chemism and represents the Qratonization in time and space. The most important eruptive period wate connected with the decaying tectonio processe: of the Variscan cycle. This late Variscan volcanism was respectively controlled and highly influenced by the meridional system of faults and that paralle with the southwestern margin of the Eastern European platiorm. In the area of intersection of the two systems. there was the absolute maximum of the
Variscan-8ubsequent cover magmatism and, at the same time, of that in northern Central Europe in general.

Garezki, R. G.; Aisberg, R. E.; Suvejsdis, P. I. u. a.

The Cover Struetures in the Byelo-Russian S.S.R: and in the Soviet Baltie Countries

7. angew. Geol., Berlin, 23 (1977) 0, pp. 430-439, 1 Nigs., 2 Refs.

The platform cover of White Russia and the Baltic countries is divided into structural complexes giving expression of the stages of tectonic development in the western Russian plate of the Eastern European platform. The development in time and space of the large cover structures can be described by mean of structural maps. The structural plans of the Lower Riphaean (?), early and late Baikalian, and Caledonian strnctural complex approximately follow the basement surface. This, certainly, proves right for the Variscan complex too, but different degrees and types of deformation, fracture tectonics as well as salt tectonics (Pripyat depression) in part are typical of the Variscan structures. The structural plan of the Kimmerian-Alpjdic complex highly departs from that of the lying complexes.

Znosko, J.

The Geological Structure in the Zone of the Tornquist-Teisseyre Line between Baltic Sea and Swietokrzyskie Gory

Z. angew. Geol., Berlin, 23 (1977) 9, pp. 439-444, 56 Reis.

The area considered is situated within the Tornquist-Teisseyre line, the southwestern marginal zone of the Prebaikalian Eastern European platform, between Baltic Sea and Swietokrzyskie Gory. The Central Polish wall and DanishPolish groove are also investigated, whose tectonic and petrographical development are described. By the Danish-Polish groove and the Central Polish wall ascending from it the territory of the People's Republic of Poland is divided into two parts, into a north-eastern, Prebaikalian consolidated one, and into a south-western one pertaining to the Palaeozoic tectonics. In this connection a discussion is once more presented of the problem Variscide distribution (STILLE) on the genesis of the area of investigation conld be confirmed and extended by the author's more recent researches.

\section{MoDLIŃski, Z.}

A Contribution to the Development of the Ordovician at the South-West Margin of the Eastern European Platform in the People's Republie of Poland

Z. angew. Geol., Berlin, 23 (1977) 9, pp. 445-449, 3 Figs., 11 Refs.

By means of a thickness and lithofacies analysis of Ordovician depositions the palaeostructural development of south-western marginal areas of the Eastern European platform is reviewed in the territory of the People's Republic of Poland and adjacent areas for the Ordovician period. From the White Russian massif in the $\mathbf{E}$ to the margin of the platform in the W a number of zones of depression and upheaval can be distinguished, which developed during the Ordovician and make their appearance with particular clearness during the Caradocian and Ashgillian stages. The immediate margin of the platform is respectively interpreted as an area where the rates of sedimentation were left behind the rate of depression, and as an area whose sediments were shifted by submarine erosion into the geosyncline extended in front of it. The knowledge of the geosynclinal zone is still incomplete. For the Ordovician period nerther a palaeostructural subdivision nor a lithofacial analysis can be made. Immediate posthumous relations in the platiorm area can be recognized, on the one hand, of the Ordovician.
NorLing, E.; SKoglund, R.

The South-West, Margin of the Eastern European Platform in the Territory of Sweden

Z. angew. Geol., Berlin, 23 (1977) 9, pp. 449-458, 2 Figs., 4 Tables, 60 Refs. New research results obtained at the south-west margin of the Eastern Europea platform in the territory of Sweden are reviewed on the basis of structuralgeological conditions, are supported by palaeomagnetic research results and knowledge of magmatic processes, and are followed by a detailed description of the stratigraphy, lithology and palaeogeography of this area. To conclude and complete the paper, a detailed literature review is presented.

WALLISER, O. H.

Problems of Geotectonic Classification of the Variscides

Z. angew. Geol., Berlin, 23 (1977) 9, pp. 459-463, 30 Refs.

The Variscides of Burope represent a tectogene having a Proterozoic-Palaeozoic development, whose crustal structure as well as the Variscan sedimentation and volcanism in this age neither speak in favour of an origin by the typicel plate-tectonic model, nor of that of the fixistic mantle diapirism. Their materia and structural origin, with the inclusion of differentiated mechanisms of convection, inay be explained by an increasing shortening of a sialic crustal field possibly still relatively mobile in part between the approaching Laurentia, Fennosarmatia and Gondwana continents. Thus the Variscides of Europe provide a clue to an evolution directed in a wide sense of both the causes and effects of tectogenetic processes.

PAPROTH, E.

Problems Raised in the IGCP Projeet Nr. 86

Z. angew. Geol., Berlin, 23 (1977) 9, pp. 463-465, 2 Figs., 12 Refs.

DUNNING, F. W.; WATSON, J.

On the Possible Bxtent of the Eastern Buropean Platform up to England and Wales

7. angew. Geol., Berlin, 23 (1977) 9, pp. 465-470, 2 Figs., 14 Reís.

The Precambrian basement of the Midland craton repeatedly exposed in Central Fngland contains metumorphic rocks overlain by a very probably Lates Precambrian volcanic-sedimentary series. In the Caledonids bordering on to the west the Lower Palaeozoic is developed in a thick geosynclinal facies, respectively presenting itself in thin platform facies having gaps and missing entirely in large areas. In South-East England, too, folded geosynclinal Lower Palaeozoic was found by boring. Devonian in Old-Red facies is above all distribnted in South-East Wales and in the surroundings of London; great parts of the

The boundaries of the Midland craton in the south and northwest are determined The boundaries of the
with fair accuracy.

Garezki, R. G.; Aisberg, R. E.

Structure and Stages of Development of the Western East European Platform within the Byelo-Russian S.S.R. and Adjacent Areas

Z. angew. Geol., Berlin, 23 (1977) 9, pp. 470-478, 6 Figs., 1 Table

The territory of the Byelo-Russian S.S.R. is widely occupied by the Russian plate, and is to a ninor degree occupied by the Ukrainian shield and Volhynian Asovian plate, both of which are parts of the Eastern European platform. Following a description of the individual major structures the tectonic development retlected in platform cover structures is represented in stages. Main stages of the platform development are the Lower Riphaean quasi-platiorm stage,
the Middle Riphaean-Iower Wendic kataplatín stage, and the Upper Wendic-Phanerozoic orthoplatform stage.

Koltschanow, W. P.

The Representation of Platform Areas on the Teetonic Map of the SouthWest Margin of the Eastern European Platform (IGCP Project 86)

\%. angew. Geol., Berlin, 23 (1977) 9, pp. 479-481

The principles and methods of making a tectonic map within the IGCP Project 86 (south-west marginal zone of the Eastern European platform) are described. Main characteristics of the platform areas - age of consolidation and position of the basement surface - are respectively reproduced by colours and isolines. The cover structure is represented by subsurface contours of a number o characteristic key horizons. Provision is made that fold 